\title{
Reinventing Nollywood: the impact of online funding and distribution on Nigerian
}

\section{cinema}

\section{Abstract}

The Nigerian film industry often referred to as Nollywood, is currently experiencing significant transformations in its mode of production and distribution. These far-reaching transformations are driven by tech-savvy Nigerian filmmakers who are willing to consider innovative models in the filmmaking practice - from crowdfunding to content distribution via online platforms - in their effort to become relevant in the changing digital global marketplace. Drawing on pertinent case studies and in-depth interviews with stakeholders in the Nigerian film industry, this paper suggests that advances in digital technologies, such as the Internet and digital media are creating new ways for 'new generation' filmmakers in Nigeria to fund and circulate their creative work to a vast global audience.

\section{Keywords}

Nollywood, new media, digital distribution, Nigerian cinema, crowdfunding, crowdsourcing, online distribution, digital media, digital filmmaking, digital cinema.

\section{Introduction}

Whilst the mode of screen content production, circulation and consumption continue to transform in an age that is driven by technological innovations, change in market dynamics and audience behaviour are radically altering traditional business models globally. The drift is overthrowing institutional relationships, cultural hierarchies, and conventional business models (Curtin et al, 2014). In Nigeria especially, some of the traditional business models 
associated with the industry have become less viable as emerging and established filmmakers are increasingly looking to the Internet as an alternative means to raise funds and distribute their work. Although some of these web-based funding and distribution models are in their infancy, current trends in Nollywood suggest that these innovative approaches to film finance and distribution are gradually establishing themselves alongside the traditional Nollywood system.

Presently in this age of social networks and global interconnectivity, new niche markets are rapidly replacing traditional markets (Anderson, 2006). Chris Anderson, in his volume The Long Tail: Why the future of business is selling less of more (2006), posits that, "now in a new era of networked consumers and digital everything the economics of such distribution are changing radically as the Internet absorbs each industry it touches, becoming store, theatre, and broadcaster at a fraction of the tradition cost” (Anderson, 2006: 6). Within the emergent Nigerian film industry, there are immense prospects and commercial opportunities offered by these transformations. This paper explores how these transformations influence emerging business models which are providing inexpensive and easy access to a global audience through Nigerian owned digital online platforms such as IROKO TV, and Afrinolly.

The methodological framework for this research is mainly qualitative in nature. The choice of a qualitative methodology is influenced by the ability of this research to tap into the reality of the current situation and to provide complex textual descriptions of how people experience the research topic. The approach included case studies and in-depth interviews with directors, producers and distributors in the Nigerian film industry. A total of ten industry practitioners were interviewed over a period of two years from 2014 to 2016. In this research, the interviews were arranged in a semi-structured manner using open-ended questions. This 
approach encouraged respondents to speak more freely about the subject in depth and enabled the interview to probe into areas that I might not have considered in advance. The research respondents were selected on the basis of their knowledge about the industry, and also their availability and willingness to participate in the research. The interview questions were based on the experiences of respondents; their approach to funding and distribution; their views on the current state of the Nigerian film industry; the challenges and prospects offered by new technologies. Furthermore, it is significant to acknowledge that most of the respondents in this research belong to a new generation of filmmakers in Nollywood that are predominantly based in Lagos, and as such represent a small sample of the overall Nollywood industry. Therefore, the specific findings in this paper are not designed to speak on behalf of all practitioners in the Nigerian film industry. Some of the interviews were conducted via social media platforms like Facebook and Skype, while others were conducted in-person. The interviews included seven filmmakers, one media entrepreneur, and two film distributors. Niyi Akinmolyan is a writer and film director. He founded Anthill studio in 2008 and has directed various feature films which include Falling (2015), Out of Luck (2015), My African Wedding (2013), Make a Move (2012) and Kajola (2009). One of his films The Arbitration (2016) has received international recognition and was screened at the 2016 Toronto International Film Festival (TIFF). Tope Oshin, a television and film director, producer and actor has produced and directed TV shows such as Hotel Majestic (2015), Tinsel (2009 2012) and The Apprentice Africa (2008). Tope has also directed short films like Ireti (2016), Hope (2016), New Horizons (2014), Till Death Do Us Part (2012), Journey to Self (2012), and produced a feature film Fifty (2015). Seyi Babatope is a writer and film director. He has directed three feature films When Love Happens Again (2016), Lunchtime Heroes (2015), and When Loves Happens (2014). Obi Emelonye is a writer, director and producer whose films such as The Mirror Boy (2011), Last Flight to Abuja (2012), Onyi Ozi (2013) and 
Oxford Gardens (2015) have received international acclaim on the festival circuit and have also been screened in movie theatres both within Africa and in countries such as the UK, and the USA. Victor Sanchez Aghahowa a screenwriter, director, and producer for film and television has directed TV dramas like Hush (2015), Hotel Majestic (2015) and Tinsel (2009 - 2014). Victor created a web series on YouTube titled How She Left My Brother (2012). Documentary filmmaker, Femi Odugbemi, is also a screenwriter, cinematographer, and photographer whose films and documentaries, in particular, Gidi Blues (2016) and Bariga Boys (2009), have won awards and recognition at various local film festivals and industry awards. Walter Taylaur is a director and writer, known for Gbomo Gbomo Express (2015), The Wages (2013) and Get Lucky (2013). Chike Maduegbuna is an IT entrepreneur who created Afrinolly a mobile app on Android that enables screen content consumers to watch short African video content on their mobile devices. Don Omope is the Head of Film Production and Strategy at Filmone production and distribution. He has produced The Wedding Party (2016), Taxi Driver: Oko Ashewo (2015) and Lunch Time Heroes (2015). Remi Ogunpitan, a media entrepreneur, has produced many TV shows in Nigeria including The Apprentice Africa (2008). The research participants provided an insight into how practitioners in Nollywood are negotiating the challenges of screen content circulation in the current digital ecosystem in Nigeria.

\section{Global film distribution, Nollywood, and digital media}

Recent discussions about the film industry have been concerned with technological innovation and the opportunities that emanate with it. As Peter Kaufman and Jen Mohan concluded in their report prepared for the Tribeca Film Institute in 2008, "the advent of digital technologies and the skyrocketing demand for online video are going to change the nature of independent film and video production, distribution, and funding forever” 
(Kaufman and Mohan, 2008: 17). Globally, the processes of circulating screen content are experiencing a "veritable revolution in the twenty-first century" (Curtin et al, 2014: 2). When considering the ready availability of titles online, it is has become obvious that established and emerging filmmakers are radically realigning their business models around innovative modes of delivery. Cunningham and Silver (2013) acknowledge that the "potential to sell directly to individual consumers of niche or mass audience could undermine the longstanding distribution dominance of the 'majors' as happened in the decimation of the music business in only a few short years” (Cunningham and Silver, 2013: 2). The major studios of Hollywood such as Walt Disney Pictures, Warner Bros Pictures, 20th Century Fox, Universal Pictures, Sony (Columbia/Tristar), Paramount Pictures and MGM/UA have for over a century maintained a dominant role in the distribution and exhibition of films worldwide (Sliver and Alpert, 2003). However, Dina Iordanova, in her essay 'Digital disruption: technological innovation and global film circulation’ (2012) suggests that new technologies are undermining the traditional distribution model of these Hollywood majors and chances are global circulation of screen content will evolve through employing multiple digital methods (Iordanova, 2012).

Nollywood has been receiving much scholarly attention in the last decade, and a cursory survey of existing academic literature on the industry indicates that there is a growing body of work about its mode of production and distribution. Whilst academic study of the impact of digital media on funding and distribution is still in its infancy, some scholars such as Brian Larkin (1997, 2004, 2008), Jade Miller (2012, 2016), Alessandro Jedlowski (2012, 2013) and Ramon Lobato (2010, 2012), have offered insights about the informality of Nollywood's distribution network. As Miller (2012) observes, the Nigerian film industry is "virtually invisible" to the international mainstream film audience due to its informality, "but throughout Sub-Sahara Africa and the global African diaspora, the cinema is not just known, 
but known as a dominant force” (Miller, 2012: 118). This notion best describes Nollywood’s current position in global media flows. As Jedlowski (2013) acknowledges, “media piracy and transnational informal circulation made Nigerian films travel all over Africa and the world, transforming them into a pan-African and global form of popular culture” (Jedlowski, 2013: 31). Jedlowski suggests that Nigerian filmmakers and distributors today see the “transnational audience as a potentially lucrative market” and are intensifying efforts to 'formalize' the distribution channel to these areas where the cinema is popular (Jedlowski, 2013: 24).

The emergence of Nigerian owned web-based platforms such as IROKO TV and Afrinolly, seem to have ushered in a new phase in the circulation of Nigerian screen content both local and international. As Femi Odugbemi points out, digital connectivity has expanded our connection to the audience (Femi Odugbemi, 2016, personal communication). Currently, in Nollywood there appears to be enhanced access to discrete diasporic audiences and improved revenue opportunities for filmmakers. As Jade Miller in her book Nollywood Central (2016) observes, Nollywood is currently witnessing the significant presence of formal money and formal interest in its distribution circuits. According to Miller (2016), “Internet-based distribution - mostly streaming services - are particularly and increasingly popular with Nollywood audiences in places where fans are likely to have the ability to easily stream fulllength movies without data or power interruption” (Miller, 2016: Chapter 5, Section 5, Para 1).

Whilst the Internet's digital network seems to offer inexpensive and easy means to promote Nollywood screen content and sell into global markets, Manuel Castells’ trilogy of the 'Information Age’ offers some vital insight about network society. Castells (1996, 1997, 1998), suggests that since information and knowledge have always been central to societies, 
the real breakthrough for modern culture has been the development of networks. Consequently, emerging and established screen content producers in Nigeria have been able to use these networked communities to develop, fund, and circulate screen contents. According to Arthur (2016), “digital media platforms enable reconnection, community building, and provide a means for reimagining the African continent through narratives rendered in online spaces” (Arthur, 2016: 50). Media convergence is resulting in the flow of content across multiple platforms, and the online marketplace is becoming increasingly important for access to transnational audiences. The interactive online and social media environment has created new opportunities and challenges for film distribution. In Henry Jenkins’ seminal work Convergence Culture: Where old and new media collide (2006). Jenkins examines the relationship between three concepts: 'media convergence, participatory culture, and collective intelligence'. In his text, he defines convergence as "the flow of content across multiple media platforms, the cooperation between multiple media industries, and the migratory behaviour of media audiences who will go almost anywhere in search of the kinds of entertainment experiences they want” (Jenkins, 2004: 2). Jenkins argues that new media technologies have allowed consumers to become more visible and influential on industry structures and media content. Therefore, by enabling people to actively seek out new information and make connections across a range of content on the web, convergence has made it easy for audiences to personalize content and contribute to media culture.

\section{Crowdfunding: an alternative finance model}

In most film industries around the world, access to finance plays a significant role in stimulating growth and development. Traditionally, a number of funding options existed for screen content creators such as government grants, private investment, debt finance and so forth. But constraints in obtaining funding from some of these sources have prompted content creators to look for alternative ways to secure funds for their productions. As Sorensen 
(2012) suggests, “crowdfunding, peer-to-peer distribution and other online financing and distribution forms are examples of such approaches and alternatives” (Sorensen, 2012: 730). The concept of crowdfunding which usually operates through web-based funding platforms is increasingly becoming pivotal to film finance and distribution. The model has attained some level of credibility among industry practitioners (Gubbins, 2012). In some countries such as the US, UK, and Australia, online financing platforms have shown relative success in partly or fully financing creative projects. Crowdfunding platforms (CFPs) like Kickstarter and Indiegogo have successfully funded some feature length movie projects such as The Age of Stupid (2009), Veronica Mars (2014), Star Trek: Renegades (2015), and Anomalisa (2015).

Unlike many other movie industries around the world, the Nigerian film industry has advanced over the years without the significant contribution from the government or international investment. Funding options available to established and emerging filmmakers are usually limited. As Obiaya (2011) notes, “the industry has depended completely on local funding, and it has grown and functioned mainly in Nigeria’s huge informal sector” (Obiaya, 2011: 143). The drought of reliable data and documentation have hindered corporate investment in Nollywood. The production budget for most Nollywood films range from US\$30,000 - US\$400,000 and funding for these projects are mostly sourced through friends, family or small-scale businessmen. The absence of well-structured government support and large-scale corporate investment possibilities for the industry makes crowdfunding an appealing option. Presently in Nollywood, funding has remained a major barrier to production and circulation of screen content. This development has prompted some screen content producers to invent creative ways to access finance. Tech-savvy content creators are bypassing (or working alongside) traditional Nollywood funding models to source contributions from audiences through online platforms. As Femi Odugbemi acknowledges, 
"the task of a producer to figure out interesting and creative ways to finance a project is now being empowered through digital technology and by the power of the Internet” (Femi Odugbemi, 2016, personal. communication).

Crowdfunding campaigns essentially rely on social media networks to connect producers with individuals that are willing to finance their creative work. As Wisse-Huiskes (2017) acknowledges, “the most important difference between 'traditional friends and family finance' and crowdfunding is the usage of social media to broaden the reach of the fundraising campaigns” (Wisse-Huiskes, 2017: 10). Whilst the phenomenon of crowdfunding is still relatively new in Nigeria, it is worth noting that the strategy of sourcing contributions from friends and family has often been the system in most Nollywood productions. As Walter Taylaur points out, "I usually operate on the old Nollywood or the old system whereby you raise funds through family and friends” (Walter Taylaur, 2016, personal communication). In the Nigerian film industry, online funding platforms could offer a more formalised way for filmmakers and producers to source contributions from individuals as they have always done. There are four main crowdfunding models available; Credit-based: producers borrow money from financiers which are repaid with interest; Donation-based: financiers contribute funds because they believe in the cause, usually backers do not receive financial benefit in return; Reward-based: financiers receive a reward with actual monetary value, often an early version of the product or service being funded; Equity-based: focus is on offering equity financing to producers, in exchange financiers receive shares of the company.

Currently, there is a gradual influx of Nigerian owned crowdfunding platforms such as Naturfund, Donate-ng, and Imeela. However, most of these online platforms are mostly dedicated to charity related work rather than film projects. The crowdfunding potential of this 
handful of platforms to provide financing prospects to Nigerian producers is regulated by the Securities and Exchange Commission (SEC) Nigeria. According to Wisse-Huiskes (2017), “currently there are no provisions relating to crowdfunding in the SEC rules” (WisseHuiskes, 2017: 12). Furthermore, the restrictive provisions in the Companies and Allied Matters Act, 1990 and Investment and Securities Act, 2007 have created a big challenge to companies and group of individuals' ambitious to raise money through the equity-based model of crowdfunding (Egene, 2016). It is significant to highlight that the restrictions on crowdfunding activities in Nigeria do not include donation-based crowdfunding. However, SEC has recently commenced arrangements to introduce rules and policies that will guide crowdfunding practice is Nigeria (Salako, 2015).

Whilst some screen content producers in Nigeria are exploring crowdfunding as alternative means to source funding for their creative project, some producers still maintain a passive attitude towards the model. As Walter Taylaur points out, “in Nigeria, there is a stigma attached to crowdfunding, it is almost like begging and we don't want to be seen as beggars in the society” (Walter Taylaur, 2016, personal communication). Although online financing models have attained some level of success in some Western countries, they are by no means always successful in ensuring production funding or distribution in Nollywood. One of Nigeria’s most respected directors Tunde Kelani’s attempt to crowdfund \$20,000 for his film Dazzling Mirage was unsuccessful. The campaign which was launched on Indiegogo only managed to raise $\$ 2,646$ from 21 backers. There are different sets of challenges faced by Nigerian content producers in utilizing the medium. Some of the obstacles include inadequate regulation and legal complications concerning the privileges and status of financiers, the absence of required fundraising skills, and extremely expensive data plans for internet connection. Also, the absence of a well-structured and secure online payment system in 
Nigeria is a major barrier to successfully crowdfunding campaigns. In Nigeria, financial transactions are not built on trust, most people are a little sceptical all of the time. There is a high level of suspicion associated with online payment systems, and many Nigerians believe the medium can be easily manipulated. So, the integrity factor is critical to the success of online funding because of the environment itself.

It is worth mentioning that some Nigerian filmmakers and producers in the diaspora have been able to able to launch successful crowdfunding drives through online funding platforms like Kickstarter. One of such successful campaigns is Damilare Sonoiki’s sitcom African Time aka African Booty Scratcher (2016). The hilarious sitcom is centered on the family of Nigerian immigrants in America who struggle to balance wanting a better life for their young son and also wanting him to maintain their traditional values and cultural identity. When the pilot for the sitcom was released In May 2016, it went viral on the internet. According to Venturesafrica.com:

African Booty Scratcher (ABS) went viral on social media, amassing over 3 million views on Facebook and over a hundred thousand views on YouTube in a little over a week. (Egbedi, 2016: para 1).

The African Booty Scratcher (ABS) funding campaign on Kickstarter was able to successfully raise US\$31,666 from 272 backers. Another successful funding campaign on Kickstarter is the feature-length documentary tilted The Boy from Mushin (2016). The film created by Joe Cohen is about Bisi Alimi, a Nigerian gay rights activist who is currently exiled in England. The documentary tells the story of Alimi from the time he was an HIV advocate in Nigeria to his coming out publicly to announce his sexuality. The film also 
provides insight about the challenges LGBT communities face in Nigeria. The funding campaign successfully raised $£ 20,720$ through 349 backers. At the time of writing this paper, both projects are still in production.

In order to encourage and secure a credible crowdfunding system in Nigeria, SEC needs to enact laws that will be essential to promote crowdfunding activities and protect both investors and producers' interests. Nigerian content producers need education on how to run successful crowdfunding campaigns. They also need to develop the skill set and capacity to convince backers about the authenticity of the creative project. Crowdfunding relies heavily on the power of social media to promote their campaign, consequently, there is the need for affordable Internet access in Nigeria. As Remi Ogunpitan points out, if there are affordable broadband services in the whole country, Nigeria would move with a speed of lightning because the Internet brings a lot of tools to the hands of people (Remi Ogunpitan, 2016, personal communication).

\section{New approaches to distribution of Nollywood content}

A vital factor in screen content distribution is the means by which the creative work is accessed by the consumer. The procedures involved sometimes play a major role in shaping consumer behaviour (Gubbins, 2012). Over the years, distribution has remained an important aspect of cinema because it provides the connection to those who wish to access and consume the creative content. In Nigeria, the network to connect screen content producers to consumers has previously been a barrier. As Femi Odugbemi points out, "for many years, the industry suffered from the fact that pirates could access the finished work so easily via VHS tapes or DVD” (Femi Odugbemi, 2016, personal communication). As the film industry witness global decline in DVD sales and the Nigerian DVD market becoming saturated (see Iordanova 2012; Jedlowski 2013), most screen content producers in Nigeria are inventing 
new circulation and exhibition strategies to remain competitive in the changing digital environment. The informality of Nollywood's distribution circuits coupled with inadequate circulation networks has over the years had a devastating effect on the producers and their ability to earn revenue from their creative work. Driven by an economic necessity for multiple, diversified revenue streams some Nigerian filmmakers in the last decade are inventing and deploying innovative strategies, using the internet as a catalyst to get their content on multiple platforms that will provide their audience access both local and international. As Arthur (2016) acknowledges:

avid Nollywood fans visit social media spaces like YouTube, subscription-based services IROKO TV (dubbed the Nigerian Netflix), Amazon Prime, and Netflix to watch Nigerian films. These individuals actively view and participate in online conversations about Nollywood; they reveal that through consuming Nigeria films on social media and connecting with other viewers who are a part of the larger African digital diaspora, the original homeland on the African continent is remediated as a new paradise. (Arthur, 2016: 50).

Whilst most of the international reputation of Nollywood is built around Africans in the diaspora, many of these networked communities have found Nollywood as an important connection to home. The result is that this network society online has expanded the filmmakers' connection to consumers that might be willing to pay for the creative content. Presently, there are many Nigerian-owned web-based content delivery platforms such as IROKO TV, IBAKA TV, Nollyland, Afrinolly and so forth that are offering hundreds of titles. 
Presently in Nigeria, the use of mobile technology in circulating screen content has become prominent in a changing digital environment. Mobile devices usage in Nigeria is rapidly increasing, according to the Nigerian Communication Commission (NCC), "there are over 150,000,000 million mobile telephone subscribers in Nigeria” (NCC.gov.ng, 2016). Mobile Internet data access in Nigeria is also increasing; in a country of over 170 million people, there are over 90 million Internet users (Punch, 2016). Average Nigerians prefer accessing the Internet using their smartphones and other mobile devices as it is cheaper and more effective than Wi-Fi connection which is scarce and extremely expensive. Furthermore, with the insufficient number of movie theatres and the decline in DVD sales in Nigeria (see Ryan, 2015), Nollywood filmmakers are leveraging on mobile technologies to create innovative platforms to distribute their creative content. As Tope Oshin acknowledges:

We have mobile apps such as Afrinolly which distributes of short films via mobile phones. The platform is opening up a lot more channels to circulate our works because currently we still have the problem of having too few cinemas (Tope Oshin, 2016, personal Communication).

Afrinolly is one of the pioneering Nigerian owned mobile platforms for screen content distribution. The mobile app allows users to watch African content produced in African movie markets, most especially Nollywood. Afrinolly Marketplace, which is a facility within the Afrinolly app, allows consumers to buy full-length movies. They can either stream these movies or download and then watch them at home offline. (Founded by Chike Maduegbuna, Afrinolly got started during the Andriod Developer Challenge in 2011. The app won the Andriod Developer Challenge - Sub-Sahara Entertainment category, with a \$25,000 cash 
prize. Originally, the platform was built to provide information about the screen industry in Africa which was mainly dominated by Nollywood. According to Chike Maduegbuna:

when we developed Afrinolly, we were asking ourselves questions like: how do you know what is going on in Nollywood? You know, I can get on to IMDB right now and I can track all manner of activities going on in Hollywood and am asking myself, OK, how do we do that in Nollywood? And that's part of the reason why that's one of the reasons we actually built the app. (Chike Maduegbuna, 2016, personal communication).

The mobile platform is developed to protect creative content from movie pirates, using Digital Rights Management (DRM) technology. As Maduegbuna explains, "When we distribute on mobile devices, we use Digital Rights Management (DRM) technology so the content cannot be pirated” (Chike Maduegbuna, 2016, personal communication). Mobile distribution platforms offer an alternative revenue stream for Nigerian screen content producers, a stream which the pirates are not short circuiting. Within the landscape of the Nigerian film industry, Afrinolly is also stimulating experiments in screen production. In 2012, the platform launched the Afrinolly Short film competition. Which focused on the next generation of African screen content creators. The competition is aimed at expanding the conversations on issues about the African continent by Africans, using short movies and documentary as a medium. They provide backward integration for emerging screen content creators to reduce the cost of production. There is a well-equipped production facility available to the filmmakers who might want to co-produce with them.

With the comparative progress in the use of mobile devices for content distribution, there are still some challenges around payment systems, as Maduegbuna points out: 
what sort of payment system do you want to use to enable transaction at local and rural levels when you cannot use your standard debit and credit cards; you do not even have that facility across the board. So a card payment system would not work in an environment like this. The best payment system would be something embedded in your mobile so you would be looking at things like working with the telecommunication companies to have operator billing 'airtime' as a means of a payment system. (Chike Maduegbuna, 2016, personal communication)

The apathy and suspicion associated with an online payment system in Nigeria have also remained a major obstacle to the advancement of content distribution via mobile devices. Despite banks providing promising online payments options via apps and other Internetenabled services, Nigerians still feel the medium is unsecured and can be easily manipulated. According to Wisse-Huiskes (2017), “the country’s two largest online shopping companies, Jumia and Konga, might have failed if not introducing its cash on delivery payment option” (Wisse-Huiskes, 2017: 10). The growth of content circulation via mobile technology is largely dependent on a secured online payment system, so individuals need to be protected from fraudulent online transactions in order to boost confidence in the system.

The opportunities that Internet-enabled distribution provides to Nigerian screen producers are also evident in the area of film marketing and promotion. According to Ryan and Hearn (2010), "Network of fans, remixers, and co-creators (which generate fan films, fan fiction, blog reviews) are all part of the social formations that are pre-cursors to markets for films, and new media tools (Facebook, Twitter, YouTube, blogs, websites) now allow filmmakers to engage with the audience ahead of and after production, creating in effect an ongoing and 
more sustainable relationship with the audience” (Ryan and Hearn, 2010: 4). As Obi Emelonye points out:

social media has also helped in the marketing of films. Before now you have to budget a lot of funds for publicity to be able to gain a bit of ground in the marketing of your films. Currently, if you explore the social media very well like we experienced in The Last Flight to Abuja (2012) where we started campaigning online such that it became a productive campaign. Before now, it could have been only on television that you could watch trailers but now, it could be watched wherever, on mobile devices; that makes the consumer think about the film and want to go pay and watch it. (Obi Emelonye, 2016, personal communication)

\section{Transnational distribution}

According to Van Hemert and Ellison (2015), “the rapid and widespread evolution of digital media, particularly access to crowdfunding platforms, cost-effective filmmaking equipment and online methods of film distribution, has had a significant impact on both filmmakers and audiences” (Van Hemert and Ellison, 2015: 45). Dina Iordanova \& Stuart Cunningham’s volume Digital Disruption: Cinema goes online (2012), provides an interesting insight into how digital innovation in the cinematic process are creating wider possibilities for the global circulation of screen content. Iordanova (2012) suggests, "that in a world where substantial population live in a diasporic condition or in a migratory mode, more and more audiences are turning to the Internet for cultural consumption that transcends borders” (Iordanova, 2012: Chapter 1, Section 3, Para 2). According to Australian scholars Stuart Cunningham and John Sinclair in their essay 'Diaspora and the media’ (2001), “The concept of diaspora can be usefully applied to understanding many of the major population movements of this century, 
and the complex process of the maintenance and negotiation of cultural identity which go with them” (Cunningham and Sinclair, 2001: 1). The transnational circulation of Nigerian films has recently been getting a lot of attention on the global stage from scholars and industry practitioners (See Jedlowski, 2012, 2013; Becker, 2013; Ajibade, 2013; Arthur, 2016). Nigerian cinema as a specific accessible content helps the African diaspora reconnect with their cultural identity. As Krings and Okome, in their essay 'Nollywood and its diaspora’ (2013) point out, “Nollywood, the Nigerian video film industry has become the most visible form of cultural machine on the Africa continent” (Krings and Okome, 2013: 1).

Unfortunately, since the video boom in the Nigerian film industry in the early 90s, the transnational distribution of Nollywood films have followed the logics of informality, opacity and small small-scale investments (Miller, 2012: 125). Alessandro Jedlowski (2013) acknowledges this notion, "thanks to the informality of Nollywood's distribution networks, pirated copy of Nigerian videos has circulated throughout the world since the mid-1990s” (Jedlowski, 2013: 26). However, the emergence of online content distribution companies such as IROKO has transformed the circulation of Nigerian screen content across borders. As Seyi Babatope points out, "the films are getting into an audience internationally and because IROKO TV is basically licensing your films, they are paying the producers of those films compensation for their film to be on their platform, so digital interface there has made that possible for the film industry to gain some money now” (Seyi Babatope, 2016, personal communication). Before the advent of digital media and the Internet, access to the Nollywood diasporic film communities was mainly through networks of both licit and illicit circulation (in VHS format and later in VCDs and DVDs. In the last decade, the emergence and growth of innovation networks have enhanced access to these various diasporic groups. 
In the Nigerian film industry, IROKO is arguably one of the leading players in online content distribution. Founded by Jason Njoku and Bastian Gotter in 2010, the platform has pioneered video-on-demand for Nollywood content. With a total of US\$35 million from private and venture capital investors such as Canal+, Kinnevik and Tiger Global Management. Presently, it is arguably one of the largest licensors of Nigerian movies, with offices in Lagos, London, and New York, the platform offers a range of online digital content delivery services which include its movie streaming subscription-based website IROKO TV. Other platforms are Iroko tv on YouTube, IgboLove, HausaLove, YourbaLove, and IROKOX which all stream Nollywood content for free on the YouTube video platform.

IROKO’s dedicated streaming platform for IROKO TV was launched in 2012, according to Bloomberg Businessweek, most of IROKO’s viewership is from the African diaspora: 22 percent is from the United Kingdom, 33 percent from United States, 7 percent from Canada, 11 percent from Nigeria and 27 percent from the rest of the world (Okeowo, 2016). As Arthur (2016) notes, “IROKO TV boasts ten million hits per day from 200 countries (Arthur, 2016: 52). IROKO acquires online licenses of screen content directly from producers and streams the content online to local and global diaspora audiences. The approach has offered original content producers in Nigeria the benefits of the industry's transnational success. In 2015, the company paid out US\$550,000 to content partners and generated 1.5 billion views through all of its distribution deals (Bright, 2016).

\section{Conclusion}

As advances in digital technologies stimulate experiments in the ways Nollywood content is produced and circulation to local and diasporic audiences, it is evident that screen content creators in Nigeria need to invent new business models to remain competitive in a digital 
business environment. At different stages of this research, the interviews with practitioners in the Nigerian film industry indicate that digital tools in the filmmaking practice have offered Nollywood practitioners the opportunity to operate as a networked community, encouraging an environment that is characterized by improved technology, efficiency, and easier logistics. When it comes to financing creative projects, the Internet is providing alternative means to raising funds through crowdfunding. However, at this stage, there is no overwhelming evidence to conclude that crowdfunding as an alternative funding model can become a single viable and sustainable model for raising finance for commercial or non-commercial Nollywood films.

In the aspect of distribution, it has become imperative to understand how traditional Nollywood distribution system limits the amount of revenue Nigerian screen content producers can make from circulating their creative content both locally and internationally. The industry's informality and the absence of a well-structured system have not helped to drive the development of Nigeria in a changing global business marketplace. As Jedlowski (2013) points out,

the absence of regulation, the ineffective copyright regime, and the low barriers to entry exposed the industry to a high degree of imitation and to an exponential level of competition, resulting in extremely rapid growth for video production. In fact, in less than twenty years, the output of the video industry increased from a few films per year in the early 1990s to around fifteen hundred per year by the mid-2000s. (Jedlowski, 2013: 28)

Globally, the approach to intellectual property rights in relation to all cultural businesses is currently experiencing drastic change (Iordanova, 2012). In Nigeria, it is evident that there is the need to formalize transactions in the industry, now that producers are inventing multiple, diversified revenue streams, by creating innovative forms of storytelling across multiple 
formats and platforms. In this age of globalization and interconnectivity, access to official data and reliable statistics is significant for planning, and planning is critical to efficiency. Far too often, directors and producers focus on the arts and then the business aspects of the industry become the afterthought. With the opportunities offered by the Internet and digital media for content producers in Nigeria to monetize their creative work and make it easier to distribute to a vast audience, there is a need for producers to become aware of the prospects of retaining ownership copyrights to their work, and protecting their intellectual property.

\section{References}

Ajibade, B. (2013) 'Nigerian Videos and Their Imagined Western Audience: The Limits of Nollywood's Transnationality', in Krings, M. and Okome, O. (eds.) Global Nollywood: The Transnational Dimensions of an African Video Film Industry. Indiana: Indiana University Press, pp. 264-84.

Anderson, C. (2006) The long tail: Why the future of business is selling less of more. New York, NY: Hyperion Books.

Arthur, T. 2016, "Nollywood Afrogeeks: Nigerian Cinema, Digital Diasporas, and African Immigrants in the United States", International Journal of E-Politics (IJEP), vol. 7, no. 3, pp. 49-64.

Becker, H. (2013) 'Nollywood in Urban Southern Africa: Nigerian Videos Films and Their Audiences in Cape Town and Windhoek', in Krings, M. and Okome, O. (eds.) Global Nollywood: The Transnational Dimensions of an African Video Film Industry, Indiana: Indiana University Press, pp. 245-63.

Bright, J. (2016) Iroko launches IrokoX online network to showcase Africa's creative talent. 
Available at: https://techcrunch.com/2016/09/09/its-time-for- african-talent/ (Accessed 12 November 2016).

Castells, M. (1996) The rise of the network society: The information age: Economy, society and culture. Malden, MA: Blackwell Publishers.

Castells, M. (1997) The information age: Economy, society and culture: V. 2: Power of identity. 2nd edn. Malden, MA: Blackwell Publishers.

Castells, M. (1998) The information age: culture. 2nd edn. Malden, MA: Blackwell Publishers.

Cunningham, S. and Silver, J. (2013) Screen distribution post-hollywood. The new king Kongs of the online world. e-book. Basingstoke, United Kingdom: Palgrave MacMillan, Kindle Edition.

Cunningham, S. and Sinclair, J. (2001) 'Diasporas and the media', in Cunningham, S. and Sinclair, J. (eds.) Floating Lives. Maryland: Rowman \& Littlefield publishers, pp. 1-34.

Curtin, M. Holt, J. and Sanson, K. (2014) Distribution revolution: Conversations about the digital future of film and television. e-book. University of California Press. Oakland California. Kindle Edition.

Egbedi, H. (2016). African booty scratcher: this sitcom by a 24-year-old aims to portray a realistic image of African immigrants. [Blog] Venturesafrica. Available at: http://venturesafrica.com/features/african-booty-scratcher-this-comedy-sitcom-by-a-24-yearold-aims-to-portray-a-realistic-image-of-african-immigrants/ (Accessed 20 Febuary 2017). Egene, G., 2016. SEC Rules Out Crowdfunding in Nigeria for Now. Thisday. [online] 
Available at: <http://www.thisdaylive.com/index.php/2016/08/15/sec-rules-outcrowdfunding-in-nigeria-for-now/> [Accessed 14 Jun. 2017].

Franklin, M. (2012) 'Internet-enabled Dissemination: Managing Uncertainty in Film Value Chain.', in Iordanova, D. and Cunningham, S. (eds.) Digital Disruption: Cinema moves online. e-book. Andrews: St Andrews Film Studies, Kindle Edition.

Gubbins, M. (2012) 'Digital Revolution: active audiences and fragmented consumption', in Iordanova, D. and Cunningham, S. (eds.) Digital Disruption: Cinema moves online. e-book. Andrews: St Andrews Film Studies, Kindle Edition.

Iordanova, D. (2012) 'Digital disruption: Technological Innovation and global film circulation', in Iordanova, D. and Cunningham, S. (eds.) Digital disruption: Cinema moves online. e-book. Andrews: St Andrews Film Studies, Kindle Edition.

Iordanova, D. and Cunningham, S. (eds.) (2012) Digital disruption: Cinema moves on-line. e-book. London, United Kingdom: St. Andrews film studies. Kindle Edition

Jedlowski, A. (2013) 'From Nollywood to Nollyworld: Processes of Transnationalization in the Nigerian Video Film Industry’, in Krings, M. and Okome, O. (eds.) Global Nollywood: The Transnational Dimensions of an African Video Film Industry. Indiana: Indiana University Press, p. .25-45.

Jedlowski, A. (2012) 'Small screen cinema: Informality and remediation in Nollywood', Television \& New Media, 13(5), pp. 431-446. doi: 10.1177/1527476412443089.

Jenkins, H. (2006) Convergence culture: Where old and new media collide. New York, NY: New York University Press.

Kaufman, P. and Mohan, J. (2008) 'The Economics of Independent Film and Video 
Distribution in the Digital Age: A Report Prepared for the Tribeca Film Institute,' Intelligent Television, New York.

Krings, M. and Okome, O. (2013). Nollywood and its Diaspora. In: M. Krings and J. Okome, ed., Globally Nollywood: The Transnational Dimensions of an African Video Film Industry. Indiana: Indiana University Press, pp.1-22.

Krings, M. and Okome, O. (2013) Globally Nollywood: The Transnational Dimensions of an African Video Film Industry. Indiana: Indiana University.

Larkin, B. (1997) 'Indian films and Nigerian lovers: Media and the creation of parallel modernities', Africa, 67(03), pp. 406-440. doi: 10.2307/1161182.

Larkin, B. (2004) 'Degraded images, distorted sounds: Nigerian video and the infrastructure of piracy’, Public Culture, 16(2), pp. 289-314. doi: 10.1215/08992363-16-2-289.

Larkin, B. (2008) Signal and noise. Durham: Duke University Press.

Lobato, R. (2010) 'Creative industries and informal economies: Lessons from Nollywood', International Journal of Cultural Studies, 13(4), pp. 337-354. doi:

$10.1177 / 1367877910369971$.

Lobato, R. (2012) Shadow economies of cinema: Mapping informal film distribution. London: Palgrave Macmillan.

Miller, J. (2012) 'Global Nollywood: The Nigerian movie industry and alternative global networks in production and distribution', Global Media and Communication, 8(2), pp. 117- 
133. doi: $10.1177 / 1742766512444340$.

Miller, J. (2016) Nollywood central. e-book. London, United Kingdom: British Film institute. Kindle Edition

NCC.gov.ng (2016) Industry statistics. Available at:

http://www.ncc.gov.ng/stakeholder/statistics-reports/industry-overview\#view- graphs-tables (Accessed 12 January 2017).

Obiaya (2011) 'A break with the past: The Nigerian video-film industry in the context of colonial filmmaking', Film History, 23(2), p. 129. doi: 10.2979/filmhistory.23.2.129.

Okeowo, A. (2016) The Netflix of Africa Doesn't need Hollywood to win. Available at: https://www.bloomberg.com/news/features/2016-02-22/the- netflix-of-africa-doesn-t-needhollywood-to-win (Accessed 12 November 2016).

Punch (2016) Nigeria's internet users reduce by 81, 415 - NCC - punch newspapers. Available at: http://punchng.com/nigerias-internet-users-fall- 81415-ncc/ (Accessed 12 January 2017).

Ryan, C. (2015) ‘New Nollywood: A sketch of Nollywood’s metropolitan new style’, African Studies Review, 58(03), pp. 55-76. doi: 10.1017/asr.2015.75.

Ryan, M.D. and Hearn, G. (2010) ‘Next-generation “filmmaking”: New markets, new methods and new business models’, Media International Australia, 136(1), pp. 133-145. doi: 10.1177/1329878x1013600115.

Salako, T., 2015. SEC moves to deepen market with rules on crowdfunding. The nation. [online] Available at: <http://thenationonlineng.net/sec-moves-to-deepen-market-with-ruleson-crowdfunding/> [Accessed 14 Jun. 2017]. 
Silver, J. and Alpert, F. (2003) ‘Digital dawn: A revolution in movie distribution?’, Business Horizons, 46(5), pp. 57-66. doi: 10.1016/s0007- 6813(03)00072-7.

Sørensen, I.E. 2012, "Crowdsourcing and outsourcing: the impact of online funding and distribution on the documentary film industry in the UK", Media, Culture \& Society, vol. 34, no. 6, pp. 726-743.

Van Hemert, T. and Ellison, E. 2015, "Queensland's film culture: the challenges of local film distribution and festival exhibition", Studies in Australasian Cinema, vol. 9, no. 1, pp. 39-51.

Willis, H. (2005) New digital cinema: Reinventing the moving image. Wallflower Press. London.

Wisse-Huiskes, S., 2017. Crowdfunding Potential for Nigeria 2017. [online] Amsterdam: CrowdfundingHub, pp.1-15. Available at: <http://www.crowdfundinghub.eu/reportcrowdfunding-potential-for-nigeria-2017/> [Accessed 14 Jun. 2017]. 